\title{
Znaczenie terapii chelatującej u pacjentów z przeładowaniem żelaza w wyniku częstych transfuzji krwi
}

\author{
Chelation therapy in patients with iron overload \\ due to frequent blood transfusions
}

\author{
Jadwiga Dwilewicz-Trojaczek, Anna Waszczuk-Gajda \\ Klinika Hematologii, Onkologii i Chorób Wewnętrznych, Warszawski Uniwersytet Medyczny
}

\begin{abstract}
Streszczenie
Najczestsza przyczyna przetadowania żelazem (IO) sa przetoczenia koncentratów krwinek czerwonych (kkcz), w mniejszym stopniu — zwiększenie wchtaniania żelaza u chorych z nieefektywna erytropoeza. Przetadowanie żelazem prowadzi do marskości/wtóknienia watroby, niewydolności serca, cukrzycy, zaburzeń endokrynologicznych, zmian w uktadzie odpornościowym, pogorszenia wyników przeszczepienia allogenicznych krwiotwórczych komórek macierzystych (allo-HSCT). W celu zapobieżenia tym powiktaniom $i$ poprawy funkcji uszkodzonych narzadów zaleca sie stosowanie chelatorów żelaza, takich jak deferoksamina, deferypron, deferazyroks. Do leczenia chelatorami żelaza kwalifikuja sie chorzy na niedokrwistości wrodzone (np. anemia sierpowatokrwinkowa, talasemie), zespoty mielodysplastyczne niższego ryzyka lub pierwotna mielofibroze, którzy sq uzaleznieni od przetoczeń kkcz, maja stę̇enie ferrytyny powyżej $1000 \mathrm{ng} / \mathrm{ml}$ albo potwierdzone w biopsji watroby lub $w$ badaniu rezonansu magnetycznego ztogi zelaza $w$ watrobie. Chorzy po allo-HSCT $z$ dtugo utrzymującym sie IO również moga być kandydatami do leczenia chelatorami żelaza. Jest coraz więcej obserwacji oraz badan klinicznych wskazujacych, ze terapia chelatujaca poprawia funkcje uszkodzonych narzadów, poprawia odpowiedź hematologiczna i wydtuża przeżycie chorych.
\end{abstract}

Słowa kluczowe: przeładowanie żelazem, hiperferrytynemia, deferoksamina, deferazyroks, deferypron

Hematologia 2016; 7, 1: 1-13

\begin{abstract}
The most common cause of iron overload (IO) are red blood cells transfusions, in less extend also increase of iron absorption from the gut due to ineffective erythropoiesis. IO leads to liver fibrosis/cirrhosis, cardiac dysfunction, diabetes and other endocrinopathies, changes in immunity worsening of survival in patients undergoing allogenic hematopoietic stem cell transplantation (allo-HSCT). To prevent and delay complications associated with iron deposition in organs, iron chelation therapy with deferoxamine, deferiprone, deferasirox in monotherapy or in combination is recommended. Chelation therapy should be considered in transfussion-dependent patients diagnosed with inherited anemias (sickle cell anemia, thalassemias), low risk myelodysplastic syndromes, primary idiopatic myelofibrosis, with ferritin concentration higher than $1000 \mathrm{ng} / \mathrm{mL}$
\end{abstract}

Adres do korespondencji: Jadwiga Dwilewicz-Trojaczek, Klinika Hematologii, Onkologii i Chorób Wewnętrznych, Warszawski Uniwersytet Medyczny, ul. Banacha 1A, 02-097 Warszawa, tel. 2259928 18, faks 2259914 18, e-mail: jadwiga.dwilewicz-trojaczek@wum.edu.pl 
or with iron depositions (confirmed in liver biopsy or nuclear magnetic resonance). Patients who have undergone allo-HSCT with persistent IO may also be candidates for treatment with iron chelators. We have more consistent data and evidences that chelating therapy improves the function of damaged organs, improves hematological response, and prolongs the survival of patients.

\section{Key words: iron overload, hiperferritinemia, deferoxamine, deferasirox, deferiprone}

Hematologia 2016; 7, 1: 1-13

\section{Wprowadzenie}

Chorzy na niedokrwistości przewlekłe - zarówno wrodzone, jak i nabyte - często wymagają przetoczeń koncentratu krwinek czerwonych (kkcz). Do niedokrwistości tych należą: talasemie, anemia aplastyczna, zespoły mielodyspastyczne (MDS, myelodysplastic syndrome), pierwotne zwłóknienie szpiku (PMF, primary myelofibrosis). Częste przetoczenia kkcz prowadzą do przeładowania organizmu żelazem (IO, iron overload). Każdy mililitr krwi w jednostce kkcz zawiera 1,1 mg żelaza. Przetoczenie $100 \mathrm{j}$. kkcz dostarcza $20 \mathrm{~g}$ lub więcej żelaza [1]. Przetoczenie $2 \mathrm{j}$./miesiąc spowoduje przetoczenie $100 \mathrm{j}$. kkcz w ciągu 4 lat, natomiast przetoczenie $4 \mathrm{j}$./miesiąc - przetoczenie $100 \mathrm{j}$. kkcz w ciągu około 2 lat. Prowadzi to do IO różnych tkanek i narządów. Uważa się, że IO pojawia się już po przetoczeniu $20 \mathrm{j}$. kkcz, a świadczy o tym wzrost stężenia ferrytyny powyżej $2000 \mathrm{ng} / \mathrm{ml}$.

\section{Patogeneza przeładowania organizmu żelazem}

U chorych $z$ nieefektywną, nasiloną erytropoezą IO może występować jeszcze przed rozpoczęciem przetoczeń kkcz. Stwierdza się to na przykład u chorych na MDS, takie jak anemia oporna na leczenie (RA, refractory anemia) i anemia oporna na leczenie $z$ obecnością patologicznych syderoblastów (RARS, refractory anemia with ringed sideroblasts). Obserwuje się wtedy gwałtowne obniżenie stężenia hepcydyny w surowicy krwi. Chorzy na MDS-RA lub MDS-RARS są obciążeni szczególnie dużym ryzykiem rozwoju IO. Mechanizm obniżenia stężenia hepcydyny nie jest ostatecznie wyjaśniony. Istotną rolę odgrywają w nim różne białka, w tym: czynnik wzrostu i różnicowania 15 (GDF-15, growth differentiation factor 15), TWSG1 (twisted gastrulation 1), białko morfogenetyczne kości (BMP, bone morphogenetic protein) i SMAD4. Hepcydyna odpowiada za prawidłową homeostazę żelaza w organizmie. W warunkach fizjologicznych nadzoruje aktywność ferroportyny — transportera błonowego żelaza (przechodzenie żelaza przez błonę komórkową enterocytów i makrofagów). Niedobór hepcydyny zwiększa ilość ferroportyny i w ten sposób wzmaga wchłanianie żelaza w przewodzie pokarmowym i uwalnianie go $z$ magazynów (makrofagów, hepatocytów).

Zwiększone stężenie żelaza przekracza możliwości wiązania go przez białko nośnikowe - transferynę, wtedy pojawia się żelazo niezwiązane $z$ transferyną (NTBI, non-transferin bound iron) i pula labilna żelaza w surowicy (LPI, labile plasma iron). Żelazo niezwiązane $z$ transferyną gwałtownie przedostaje się do hepatocytów, komórek mięśnia sercowego, tkanek endokrynnych i innych. Zwiększa się pula labilnego żelaza komórkowego (LIP, cellular labile iron pool). Wzrasta wytwarzanie reaktywnych rodników hydroksylowych, co powoduje destrukcję organelli, uszkodzenia DNA, białek i lipidów. Dochodzi do śmierci komórki lub procesów włóknienia $[2,3]$.

Najczęstszą przyczyną IO jest uzależnienie od przetoczeń kkcz. Czasami współistnieje mechanizm zwiększonego wchłaniania żelaza w nasilonej nieefektywnej erytropoezie.

\section{Konsekwencje kliniczne przeładowania organizmu żelazem}

Skutkami przeładowania IO są: marskość wątroby lub jej zwłóknienie, rozwój nowotworu wątroby, upośledzenie funkcji serca (niewydolność serca [HF, heart failure], zaburzenia rytmu) i nagła śmierć sercowa, zaburzenie czynności narządów wydzielania wewnętrznego (cukrzyca, niepłodność, niedoczynność tarczycy, zaburzeń wzrostu $\mathrm{u}$ dzieci). Żelazo niezwiązane $z$ transferyną powoduje także uszkodzenie stawów, jest toksyczne dla hematopoezy, pogarsza wyniki po transplantacji komórek krwiotwórczych oraz zwiększa częstość zakażeń bakteryjnych i grzybiczych [4].

Ciężkie IO wątroby nie jest zbyt częste (poza chorymi na talasemię) w przebiegu nieefektywnej erytropoezy nabytej, na przykład w MDS, gdyż czas trwania syderozy jest zbyt krótki, by spowodować marskość narządu. Ciężkie IO prowadzi do rozwoju marskości/włóknienia lub rozwoju raka wątroby 
(>7 mg Fe/g suchej wagi wątroby). Przeładowanie żelazem wątroby poprzedza rozwój tego procesu w mięśniu sercowym. Natomiast funkcja serca szybciej ulega upośledzeniu, szczególnie u starszych chorych $z$ towarzyszącymi chorobami serca. Ciężkie IO wątroby utrudnia usuwanie żelaza $z$ serca (jest ono szybciej usuwane $z$ wątroby niż $z$ serca).

Stężenie żelaza w sercu (CIC, cardiac iron concentration) powyżej $600 \mu \mathrm{g}$ Fe/g masy i powyżej 23 g przetoczonego żelaza powoduje rozwój HF. Do oceny IO serca służy badanie metodą rezonansu magnetycznego (MRI, magnetic resonance imaging). Skrócenie T2* mięśnia sercowego do wartości poniżej $20 \mathrm{~ms}$ wskazuje na zwiększenie zawartości żelaza w sercu, a skrócenie T2* do wartości poniżej $10 \mathrm{~ms}$ wiąże się $z$ wyższym ryzykiem zmniejszenia frakcji wyrzutowej serca (zdekompensowana funkcja serca skurczowa i rozkurczowa) i zaburzeń rytmu serca [5, 6]. Według Takatoku i wsp. [7] wśród chorych na MDS ze stężeniem ferrytyny powyżej $1000 \mathrm{ng} / \mathrm{ml} \mathrm{HF}$ stwierdzono u $24 \%$, a niewydolność wątroby - u $6,7 \%$. Także Malcovati i wsp. [8] stwierdzali HF u $51 \%$, zakażenia u $31 \%$, marskość wątroby zaś u $8 \%$ chorych na MDS. W badaniu Malcovati z 2007 roku [9] wykazano częstsze występowanie chorób towarzyszących u chorych na MDS uzależnionych od przetoczeń kkcz. Chorzy ci doznają większej liczby zdarzeń sercowych, częściej chorują na cukrzycę, mają zaburzenia oddychania oraz więcej chorób wątroby i zakażeń, w tym grzybiczych, niż chorzy niewymagający przetoczeń kkcz. W Polsce chorzy na MDS stanowią liczną grupę uzależnionych od przetoczeń kkcz. W tej grupie, poza wyżej wymienionymi powikłaniami, stwierdzono skrócenie czasu przeżycia oraz prawdopodobieństwo zwiększonego ryzyka progresji w ostrą białaczkę szpikową (AML, acute myloid leukemia) [10].

Ciężkie niedokrwistości, które są powodem przetoczeń kkcz, mogą także ulec nasileniu w wyniku toksycznego działania żelaza niezwiązanego $z$ transferyną. Dowiedziono, że tworzenie in vitro kolonii wczesnych komórek ukierunkowanych erytropoezy (BFU-E, burst forming unit) jest obniżone $\mathrm{u}$ chorych $\mathrm{z}$ wysokim stężeniem ferrytyny [11].

Przeładowanie żelazem pogarsza wyniki przeszczepienia allogenicznych krwiotwórczych komórek macierzystych (allo-HSCT, allogeneic hematopoietic stem cell transplantation). Ponadto chemioterapia przed przeszczepieniem powoduje nasilone uwalnianie żelaza $z$ depozytów komórek. $\mathrm{Na}$ „przeszczepowy wskaźnik żelazowy” składają się następujące elementy: liczba przetoczonych kkcz przed przeszczepieniem ( $>25 \mathrm{j}$. $-1 \mathrm{pkt}$ ), stężenie ferrytyny $(1000 \mu \mathrm{g} / 1-1 \mathrm{pkt})$, złogi żelaza w szpiku (6 pkt. w skali Gale [punktacja 0-6]) [12]. Za wysoki „wskaźnik żelazowy” uznano jego wartość powyżej 2. Wskaźnik ten jest predyktorem przeżycia chorych po allo-HSCT — im jest wyższy, tym większe jest ryzyko zgonu [13]. Według Lim i wsp. [14] chorych ze stężeniem ferrytyny powyżej $1000 \mathrm{ng} / \mathrm{ml}$ przed transplantacją cechują krótsze przeżycie całkowite (OS, overal survival) $(\mathrm{p}=0,007)$, krótsze przeżycie wolne od choroby (DFS, disease-free survival) $(\mathrm{p}=0,015)$ i częstsze nawroty $(\mathrm{p}=0,024)$, nie stwierdzono natomiast wyższej śmiertelności związanej z leczeniem (TRM, therapy-related mortality) $(\mathrm{p}=0,250)$. Według Pullarkat i wsp. [15] u chorych ze stężeniem ferrytyny powyżej $1000 \mathrm{ng} / \mathrm{ml}$ przed allo-HSCT wzrastała śmiertelność do 100 dni od przeszczepienia $(\mathrm{p}<0,013)$. Chorych tych cechowało krótsze OS $(p=0,004)$, częściej występowały u nich ostra choroba przeszczep przeciw gospodarzowi (aGvHD, acute graft versus host disease) $(\mathrm{p}=0,001)$ i posocznice $(\mathrm{p}=0,032)$. Podobne wyniki uzyskali inni autorzy $[16,17]$. Podsumowując, na podstawie tych badań można stwierdzić, że im jest wyższe stężenie ferrytyny w surowicy przed allo-HSCT, tym gorsze jest przeżycie po przeszczepieniu komórek macierzystych.

Obserwowano również wpływ stężenia ferrytyny przed rozpoczęciem leczenia azacytydyną na wyniki leczenia u chorych na MDS lub AML z liczbą blastów 20-30\%. Mediana stężenia ferrytyny w analizowanej grupie wynosiła $1001 \mathrm{ng} / \mathrm{ml}$ (21-5548), a u chorych ze stężeniem ferrytyny nieprzekraczającym $1000 \mathrm{ng} / \mathrm{ml}$ obserwowano odpowiedź na leczenie azacytydyną w porównaniu $z$ pacjentami, u których stężenie ferrytyny wynosiło powyżej $1000 \mathrm{ng} / \mathrm{ml}$ (odpowiednio całkowita odpowiedź na leczenie $82,6 \%$ v. 24,2\% [18].

Przeładowanie żelazem zwiększa częstość zakażeń bakteryjnych i grzybiczych. W takich przypadkach dochodzi do upośledzenia chemotaksji i fagocytozy makrofagów i neutrofilów. Bakterie i grzyby wykorzystują żelazo gospodarza. Patogeny te tworzą i wydzielają syderofory wiążące $\mathrm{Fe}^{+3}$, które w komórce przechodzi w rozpuszczalne $\mathrm{Fe}^{+2}$. Candida albicans nie wytwarza syderoforów, wykorzystując żelazo syderoforów innych mikroorganizmów. Jako źródło żelaza C. albicans wykorzystuje także hemoglobinę ( $\mathrm{Hb})$, ferrytynę, transferynę oraz żelazo z puli labilnej komórkowej po destrukcji tkanek (np. po urazie) [19]. Kontoghiorghes i wsp. [20] wykazali, że do najczęstszych zakażeń u chorych na talasemię należą infekcje bakteryjne, między innymi: Staphylococcus 
sp., Yersinia enterocolica, Klebsiella sp. Proteus sp. Pseudomonas aeruginosa, oraz grzybicze: Cryptococcus neoformans, Candida sp. Aspergillus; rzadko Mycobacterium tuberculosis.

\section{Leczenie chelatorami żelaza}

Wytyczne różnych organizacji i towarzystw naukowych dotyczące wskazań do leczenia chelatującego żelazo różnią się pod względem stężenia ferrytyny, przy którym jest rekomendowane rozpoczęcie leczenia, rodzajem leku czy czasem trwania terapii. Gattermann i wsp. [21] dokonali przeglądu międzynarodowych wytycznych dotyczących leczenia IO, w których zawarto zalecenia stosowane we Włoszech [22], Wielkiej Brytanii (UK MDS Guidelines Group) [23], Japonii (Nagasaki Group) [24] i Stanach Zjednoczonych (NCCN, National Comprehensive Cancer Network) [25]. Leczenie IO u chorych na MDS przedstawiono również między innymi w zaleceniach Merseyside and Cheshire Cancer Network Group [26], North of England Cancer Network (2010), Alberta Health Service (2009), Austrian MDS Platform (2008), Canadian consensus guideline (2008), MDS Foundation [27], izraelskich, Iron Disorders Institute (2006) i tajwańskich [28].

Przykładowo w rekomendacjach NCCN z 2016 roku [25] zaleca się stosowanie deferazyroksu lub deferoksaminy w celu zmniejszenia IO u chorych, którzy otrzymali lub otrzymają więcej niż 20 transfuzji kkcz, a stężenie ferrytyny w surowicy wynosi powyżej $2500 \mathrm{ng} / \mathrm{ml}$, leczenie chelatujące zaś należy stosować w celu obniżenia stężenia ferrytyny do poniżej $1000 \mathrm{ng} / \mathrm{ml}$. Według większości wytycznych kwalifikacja do leczenia chelatorami żelaza następuje przy stężeniu ferrytyny ponad $1000 \mathrm{ng} / \mathrm{ml}$. W wytycznych austriackich wskazaniem do rozpoczęcia tego leczenia jest stężenie ferrytyny powyżej $2000 \mathrm{ng} / \mathrm{ml}$, niezależnie od liczby transfuzji. W zaleceniach włoskich natomiast nie podano stężenia ferrytyny, przy którym należy rozpocząc tę terapię.

Leczenie chelatujące, według zaleceń polskich ekspertów [29, 30] i wymienionych wyżej międzynarodowych grup, należy stosować u chorych, którzy mogą odnieść korzyść ze stosowania chelatorów żelaza, tj. u chorych:

- na MDS niższego ryzyka (niski i pośredni-1 Międzynarodowy Wskaźnik Prognostyczny [IPSS, International Prognostic Scoring System]), chorzy na RA, RARS lub zespół 5q-; - na niedokrwistości z nieefektywną erytropoezą wymagający licznych transfuzji krwi, tj. na niedokrwistość sierpowatokrwinkową, niedokrwistość aplastyczną, talasemie zależne od przetoczeń (TDT, transfusion-dependent thalassemia), zespół Blackfana-Diamona, niedokrwistość Fanconiego;

- wymagających przetoczenia kkcz 2 j./miesiąc przez rok i dłużej (stosowanie tak długo, jak długo chory otrzymuje kkcz);

- ze stężeniem ferrytyny w surowicy powyżej $1000 \mu \mathrm{g} / \mathrm{l}$

- oraz u chorych, u których oczekiwane przeżycie wynosi co najmniej rok i/lub nie stwierdza się bardzo ciężkich schorzeń współistniejących.

Leczenie chelatorami żelaza powinno być rozważone również u chorych leczonych przetoczeniami kkcz z grupy IPSS pośredniego-2 lub wysokiego ryzyka [31]:

- gdy odpowiadają na leczenie, co daje nadzieję na wydłużenie ich czasu przeżycia;

- kandydaci do allo-HSCT, nawet jeśli są leczeni przetoczeniami kkcz krócej niż rok, ale stężenie ferrytyny przekracza $1000 \mathrm{ng} / \mathrm{ml}$ [28].

\section{Deferoksamina}

Deferoksamina łączy się z żelazem w stosunku 1:1, źle się wchłania $z$ przewodu pokarmowego, a wydalana jest przez nerki oraz przewód pokarmowy (mogą wystąpić rdzawe zabarwienie moczu i czarne stolce). Dawka dobowa leku wynosi 25-40 mg/kg (20-60 mg/kg), może być podawana podskórnie, dożylnie i domięśniowo (ChPL $D e$ sferal $\left.^{\circledR}\right)$ [32]. Pacjenci ze stężeniem ferrytyny poniżej $2000 \mathrm{ng} / \mathrm{ml}$ wymagają dawki $25 \mathrm{mg} / \mathrm{kg} \mathrm{mc}$./ /dobę,zestężeniem2000-3000 ng/ml-35mg/kg mc./ /dobę, chorzy $z$ wyższym stężeniem ferrytyny mogą wymagać nawet do $60 \mathrm{mg} / \mathrm{kg} \mathrm{mc}$./dobę. Lek jest podawany podskórnie lub dożylnie. Zaleca się długotrwałe stosowanie deferoksaminy we wlewach podskórnych. Czas takiego wlewu przez pompę powinien wynosić 10-12 godzin przewlekle, 5-7 dni w tygodniu. Przed rozpoczęciem leczenia wskazane jest wykonanie badań okulistycznego i audiometrycznego. Do najczęstszych działań niepożądanych należą: odczyny skórne w miejscu podania leku (rumień, pokrzywka, świąd), zawroty głowy, drgawki, nudności, wymioty, bóle brzucha, uszkodzenia siatkówki i zaburzenia widzenia, powstanie zaćmy, uszkodzenie słuchu, hipotonia, niemiarowość serca, a także zaburzenia wzrostu u dzieci [33]. Dlatego, gdy deferoksaminę stosuje się u dzieci, konieczne są regularne kontrole wzrostu - co 3 miesiące. Brak wspólpracy chorego w zakresie stosowania długotrwałych wlewów może być przyczyną braku poprawy lub nasilenia IO. 


\section{Deferypron}

Deferypron był pierwszym doustnym chelatorem żelaza. Jego zastosowanie zaleca się w poprzetoczeniowym IO u chorych $z$ talasemią, gdy leczenie deferoksamina jest przeciwwskazane lub nieadekwatne (ChPL Ferriprox $\left.{ }^{\circledR}\right)$ [34]. Lipofilność cząsteczki deferypronu umożliwia dostanie się tego leku do miocytów. Łączy się on z żelazem w stosunku 3:1, dobrze się wchłania w przewodzie pokarmowym, a wydalany jest przez nerki. Okres półtrwania wynosi 3-4 godzin. Dobowa dawka leku wynosi $75-100 \mathrm{mg} / \mathrm{kg} \mathrm{mc}$./dobę (dawka podzielona $3 \times /$ d.). U chorych na talasemię obserwowano działania niepożądane w postaci neutropenii $(8,5 \%)$, a także zdarzały się przypadki agranulocytozy. U części chorych na MDS już wyjściowo stwierdza się neutropenię, dlatego lek ten nie ma rejestracji u chorych na MDS i nie zaleca się jego stosowania w tej grupie.

\section{Deferazyroks}

Deferazyroks łączy się $z$ żelazem w stosunku $2: 1$. Lek dobrze wchłania się $z$ przewodu pokarmowego (ChPL Exjade ${ }^{\circledR}$ ) [35]. Okres półtrwania wynosi 12-16 h/dobę. Dawka wynosi 20-30 mg/kg mc./ /dobę; lek podaje się doustnie, raz/dobę, na czczo, co najmniej 30 min przed posiłkiem - należy go rozpuścić $\mathrm{w}$ wodzie, soku pomarańczowym lub jabłkowym, tabletek nie należy żuć ani połykać w całości. Lek jest wydalany przez przewód pokarmowy. Do najczęstszych działań niepożądanych należą: nieprogresywny wzrost stężenia kreatyniny, biegunka, wymioty, bóle brzucha, zaczerwienienie skóry, zaparcia, wzrost aktywności enzymów wątrobowych. Pacjenci powinni być poinformowani o możliwych działaniach niepożądanych w celu poprawy stosowania się do zaleceń lekarskich. W razie wystąpienia biegunki należy wykluczyć inne przyczyny, dbać o nawodnienie chorego, a po wykluczeniu przyczyn infekcyjnych i ustaleniu, że biegunka jest związana $z$ lekiem, można rozważyć zastosowanie leków zapierających (loperamid). Deferazyroks powinno się stosować wyłącznie u pacjentów $z$ wyjściowym stężeniem kreatyniny $\mathrm{w}$ surowicy mieszczącym się w granicach normy odpowiedniej dla wieku pacjenta. W badaniach klinicznych u około $36 \%$ chorych wystąpiło zależne od dawki zwiększenie stężenia kreatyniny w surowicy o $33 \%$ w co najmniej 2 kolejnych oznaczeniach. U około $2 / 3$ wyżej wymienionych chorych ze zwiększeniem stężenia kreatyniny w surowicy powyżej $33 \%$ od wyjściowej wartość ta obniżała się do ponizej $33 \%$, bez dostosowywania dawki. U pozostałej $1 / 3$ chorych zwiększenie stężenia kreatyniny nie zawsze odpowiadało na zmniejszenie dawki lub przerwanie leczenia. Szczególną uwagę należy zwrócić na monitorowanie stężenia kreatyniny w surowicy u pacjentów przyjmujących leki pogarszające czynność nerek. Podczas porejestracyjnego stosowania produktu w niektórych przypadkach pogorszenie czynności nerek prowadziło do niewydolności wymagającej czasowych lub przewlekłych hemodializ. W sytuacji wzrostu stężenia kreatyniny zaleca się odstawienie leku i obserwację, po powrocie stężenia do wartości prawidłowych natomiast można rozważyć powrót do dawki wyjściowej lub ją zmniejszyć.

Agencja ds. Żywności i Leków (FDA, Food and Drug Administration) zatwierdziła deferazyroks w Stanach Zjednoczonych do „leczenia przewlekłego przeładowania żelazem, spowodowanym przetaczaniem krwi u chorych w wieku 2 lata i starszych”. Według zaleceń European Medicines Agency (EMA) lek jest wskazany do leczenia przewlekłego IO spowodowanego przetaczaniem krwi, jeśli leczenie deferoksaminą jest przeciwwskazane lub nieadekwatne. Pacjenci $z$ większym nagromadzeniem żelaza wymagają większych dawek deferazyroksu w celu uzyskania znaczącego obniżenia stężenia ferrytyny [36]. W Polsce program lekowy obejmujący doustne leczenie nadmiaru żelaza $\mathrm{w}$ organizmie jest dostępny jedynie dla dzieci; nie obejmuje dorosłych poza pacjentami, którzy rozpoczęli leczenie przed 18. rokiem życia i kontynuują je pod warunkiem niespełnienia kryteriów wykluczenia. Natomiast według zaleceń włoskich [37] skuteczność, postać doustna leku, odpowiednia kinetyka i czas działania powodują, że deferazyroks jest lekiem $z$ wyboru w terapii chelatującej w MDS (siła zalecenia B).

Potencjalny mechanizm działania deferazyroksu, poza działaniem chelatującym, obejmuje bezpośredni wpływ na klon nowotworowy i mikrośrodowisko szpiku, redukcję czynników oksydacyjnych, które korelują $z$ nieefektywną hematopoezą, hamowanie czynnika jądrowego $\kappa \mathrm{B}(\mathrm{NF}-\kappa \mathrm{B}$, nuclear factor $\kappa B$ ) prowadzące do zmniejszenia transkrypcji czynników antyapoptotycznych, cytokin lub cząsteczek adhezyjnych, które mogą wpływać na erytropoezę, a także promowanie uwalniania żelaza $z$ magazynów powodujące jego zużycie przez komórki erytropoetyczne. Sugeruje się także wzrost stężenia endogennej erytropoetyny [38]. Trwa randomizowane prospektywne, wieloośrodkowe badanie TELESTO (NCT00940602) służące ocenie klinicznej korzyści z leczenia chelatującego deferazyroksem u 630 chorych na MDS, w którym pierwotnymi punktami końcowymi są przeżycie wolne 
Tabela 1. Charakterystyka chelatorów żelaza (zaadaptowano z [39], z modyfikacją)

Table 1. Summary of iron chelators (adapted from [39], with the modification)

\begin{tabular}{|l|l|l|l|}
\hline Właściwości & Deferoksamina & Deferypron & Deferazyroks \\
\hline Chelator: żelazo & $1: 1$ & $3: 1$ & $2: 1$ \\
\hline Droga podania & Podskórnie lub dożylnie & Doustnie & Doustnie \\
\hline Standardowa dawka [mg/kg mc./d.] & $25-50$ & 75 & $20-30$ \\
\hline Podawanie & $8-24$ h przez 5-7 dni/tydzień & 3 razy/d. & 1 raz/d. \\
\hline Działania niepożądane & $\begin{array}{l}\text { Reakcje miejscowe, } \\
\text { uszkodzenie wzroku, } \\
\text { uszkodzenie słuchu, } \\
\text { neurologiczne, infekcyjne }\end{array}$ & $\begin{array}{l}\text { Agranulocytoza, } \\
\text { neutropenia, } \\
\text { problemy stawowe }\end{array}$ & $\begin{array}{l}\text { Zaburzenia żołądkowo- } \\
\text {-jelitowe, niewydolność } \\
\text { nerek }\end{array}$ \\
\hline Zalety & $\begin{array}{l}\text { Dostępne długoterminowe } \\
\text { dane na temat skuteczności, } \\
\text { toksyczności }\end{array}$ & $\begin{array}{l}\text { Może wykazywać dużą } \\
\text { przewagę w sytuacji } \\
\text { przeładowania serca } \\
\text { żelazem }\end{array}$ & $\begin{array}{l}\text { Jedyny doustny chelator } \\
\text { żelaza do przyjmowania } \\
\text { raz/d. - łatwiejsza } \\
\text { współpraca }\end{array}$ \\
\hline Wady & $\begin{array}{l}\text { Toksyczność } \\
\text { Problemy we współpracy } \\
\text { zchorym (długi czas } \\
\text { podawania leku) }\end{array}$ & $\begin{array}{l}\text { Konieczność częstych } \\
\text { kontroli morfologii krwi }\end{array}$ & $\begin{array}{l}\text { Brak długoterminowych } \\
\text { wyników badań } \\
\text { Wysoki koszt }\end{array}$ \\
\hline
\end{tabular}

od zdarzeń (zgonu, powikłań kardiologicznych, wątrobowych itd.) oraz bezpieczeństwo terapii. Przekazanie pierwszych doniesień na temat tego badania jest planowane na luty 2018 roku (zakończenie rekrutacji do badania nastąpiło 12.2014).

$\mathrm{W}$ trakcie leczenia chelatującego ważna jest ocena stężenia ferrytyny co 3 miesiące, a także regularna ocena wydolności narządowej (stężenia kreatyniny, enzymów wątrobowych, badanie słuchu i wzroku). Po obniżeniu stężenia ferrytyny do wartości poniżej $500 \mathrm{ng} / \mathrm{ml}$ zależnie od tego, jak często chory wymaga przetoczeń kkcz, należy rozważyć zaprzestanie leczenia.

Charakterystyka, dawkowanie i działania niepożądane wymienionych wyżej leków przedstawiono w tabeli 1 [39].

\section{Wpływ na przeżycie chorych}

Mainous i wsp. [40] dokonali metaanalizy badań dotyczących ewentualnego wpływu leczenia chelatorami żelaza na OS chorych; zidentyfikowano 8 badań obserwacyjnych $z$ całkowitą liczbą pacjentów 1562. Stwierdzono, że w grupie chorych otrzymujących chelatory żelaza OS było dłuższe niż $\mathrm{u}$ chorych, u których tego leczenia nie stosowano. Poniżej przedstawiono najważniejsze z 8 badań obserwacyjnych $z$ tej metaanalizy, w których stosowano różne chelatory żelaza.

$\mathrm{W}$ nierandomizowanym, obserwacyjnym badaniu grupy frankofońskiej (GFM, Groupe Francophone des Myélodysplasies) analizą objęto 97 chorych na MDS z IPSS niskiego ryzyka, którzy przez miesiąc wymagali przetoczenia kkcz [41]. Spośród całej grupy $45 \%$ chorych poddano adekwatnemu leczeniu chelatującemu, natomiast $55 \%$ chorych nie otrzymywało chelatorów żelaza. Za adekwatną terapię chelatującą uważano taką, w ramach której chelatory stosowano przez co najmniej 6 miesięcy i był to jeden $z$ trzech leków: deferoksamina w dawce $40 \mathrm{mg} / \mathrm{kg} \mathrm{mc}$. (8-12 h $\geq 3$ dni/tydzień), deferazyroks w dawce $20-30 \mathrm{mg} / \mathrm{kg} \mathrm{mc}$./dobę, deferypron w dawce $30-75 \mathrm{mg} / \mathrm{kg} \mathrm{mc}$./dobę. W analizie wieloczynnikowej adekwatna terapia chelatująca była najsilniejszym niezależnym czynnikiem rokowniczym. W badaniu tym stwierdzono wydłużenie OS chorych, u których stosowano leczenie chelatujące żelazo w porównaniu $z$ chorymi, których tak nie leczono (mediana OS wynosiła 124 miesiące v. 53 miesiące; $\mathrm{p}<0,05)$. U chorych, u których leczenie chelatujące nie było adekwatne, mediana przeżycia wynosiła 85 miesięcy [41]. W kolejnym badaniu obserwacyjnym Leitcha i wsp. [42] grupe kontrolną dla analizowanych chorych dobierano zależnie od ryzyka według IPSS, liczby cytopenii, stanu ogólnego i liczby przetoczonych jednostek kkcz. Stwierdzono wydłużenie przeżycia chorych, u których stosowano leczenie chelatujące żelazo w porównaniu $z$ chorymi, których takiej terapii nie poddano (4-letnie OS osiagnęło 64\% v. 49\% chorych; $\mathrm{p}<0,05$; mediana $>226$ miesięcy $v .40$ miesięcy; $\mathrm{p}=0,003$ [ [42]. Zależność między leczeniem chelatującym a przeżyciem i jego ewentualny korzystny wpływ wydaje się silniejszy w MDS nie-RARS niż w MDS-RARS [43]. W retrospektywnej analizie matched-pair, na podstawie Rejestru Düsseldorf, stwierdzono wydłużenie OS chorych, u których stosowano 
leczenie chelatujące żelazo w porównaniu $\mathrm{z}$ chorymi, których tak nie leczono (mediana OS odpowiednio 75 miesięcy $v$. 49 miesięcy; $\mathrm{p}=0,002$ ) [44]. W 5-letnim, nieinterwencyjnym badaniu prospektywnym, do którego włączono 534 chorych na MDS niskiego ryzyka $z$ poprzetoczeniowym IO, po 2 latach obserwacji stwierdzono, iż stosowanie leczenia chelatującego było związane $z$ dłuższym OS $(104,4$ miesięcy $v$. 52,2 miesięcy; $\mathrm{p}=0,001)$ i mniejszą liczbą zdarzeń sercowych [45]. W badaniu Delforge i wsp. [46] leczeniem chelatującym objęto $88 \%$ chorych ze stężeniem ferrytyny o wartości większej lub równej 1000 ng/ml. Spośród 80 chorych, u których zastosowano leczenie chelatujące, $70 \%$ chorych było leczonych adekwatnie - głównie deferazyroksem lub deferoksaminą w skojarzeniu $z$ deferazyroksem. Całkowite przeżycie wynosiło 10,2 roku u pacjentów chelatowanych i 3,1 roku u chorych, u których nie stosowano leczenia chelatującego (p < 0,001) [46]. Remacha i wsp. [47] do retrospektywnego badania, prowadzonego od marca 2010 roku do marca 2011 roku w 47 hiszpańskich szpitalach, włączyli 263 chorych na MDS niższego ryzyka (IPSS niski lub pośredni-1), zależnych od transfuzji, którzy otrzymali co najmniej $10 \mathrm{j}$. kkcz. W ocenie badaczy IO odpowiadało za $70 \%$ powikłań wątrobowych i $26,9 \%$ powikłań endokrynologicznych. Leczeniu chelatującemu, trwającemu co najmniej 6 miesięcy, poddano 96 chorych; najczęściej stosowanym lekiem był deferazyroks. Pacjentów, u których zastosowano leczenie chelatujące, cechowały istotnie statystycznie dłuższe OS ( $p<0,001)$, przeżycie wolne od białaczki $(\mathrm{p}=0,007)$ oraz przeżycie wolne od zdarzeń sercowych $(\mathrm{p}<0,001)$ [47]. W analizie retrospektywnej Komrokji i wsp. [48] w populacji chorych niższego ryzyka stwierdzono poprawę przeżycia, gdy stosowano u nich leczenie chelatujące żelazo w porównaniu $\mathrm{z}$ chorymi, których tak nie leczono, i przeżycie wynosiło, odpowiednio, 59 miesięcy w porównaniu z 33,7 miesiąca $(\mathrm{p}=0,013)$.

Według Mainous i wsp. [40] wyniki metaanalizy dotyczące przeżycia należy traktować $z$ ostrożnością między innymi dlatego, że jest w niej zebranych kilka niewielkich badań, w których przedstawiano pozytywne rezultaty (co może podkreślać całościowy pozytywny efekt), nie ma badań randomizowanych i, co więcej, w interpretacji badań obserwacyjnych (nieinterwencyjnych) może dojść do tak zwanego błędu selekcji, tj. wyboru „lepiej” rokujących chorych do danego sposobu leczenia, w tym przypadku chelatującego.

\section{Wpływ na funkcje narządów}

W prospektywnym nierandomizowanym badaniu II fazy stosowano deferypron u 38 chorych $z$ rozpoznaniami innymi niz talasemia, w tym 18 chorych na MDS. Dwudziestu chorych zakończyło 12-miesięczne leczenie, uzyskując negatywny bilans żelazowy, u 75\% stwierdzono obniżenie stężenia ferrytyny o $20 \%$, a 2 chorych stało się niezależnych od transfuzji [49]. W badaniu EPIC (Evaluation of Patients' Iron Chelation with Exjade) 175 spośród 341 chorych na MDS zakończyło leczenie deferazyroksem [50,51]. Uzyskano obnizenie stężenia ferrytyny o $253 \mathrm{ng} / \mathrm{ml}$ od wartości wyjściowych $(2730 \mathrm{ng} / \mathrm{ml})$, podobnie jak obniżenie stężenia LPI ( $\mathrm{p}=0,002)$. Zaobserwowano również zmniejszenie aktywności aminotransferazy alaninowej (ALT, alanine aminotransferase), które korelowało $\mathrm{z}$ obniżeniem stężenia ferrytyny $(\mathrm{p}<0,0001)$.

W grupie 292 dorosłych japońskich chorych $z$ niedokrwistościami zależnymi od transfuzji (najczęściej MDS, anemia aplastyczna, aplazja czystoczerwonokrwinkowa, mielofibroza) $43 \%$ chorych było wcześniej leczonych deferoksaminą w ciągłych wlewach, codziennie, uzyskując obniżenie stężenia ferrytyny o $1135 \mathrm{ng} / \mathrm{ml}$, aktywności aminotransferaz (asparaginianowej [AST, aspartate aminotransferase] $-9,2 \mathrm{mj} . / \mathrm{ml}$, ALT $-28,8 \mathrm{mj} . / \mathrm{ml}$ ), normalizację stężenia glukozy na czczo $(-4,8 \mathrm{mg} / \mathrm{dl})$. W populacji koreańskiej u 96 chorych $z$ poprzetoczeniowym IO (43 chorych na MDS) leczonych przez rok deferazyroksem stwierdzano systematyczne obniżanie stężeń ferrytyny i żelaza w watrobie (LIC, liver iron concentration) oraz zmniejszenie aktywności aminotransferaz [52]. Poprawy takiej nie obserwowano, a wręcz stwierdzano pogorszenie tych parametrów, jeśli wlewy były stosowane w trybie przerywanym, co 2 tygodnie [7]. W innym badaniu, prospektywnym, u 24 chorych na MDS zależnych od transfuzji stwierdzono istotne obniżenie stężenia LIC w 24 i 52 miesiące od włączenia leczenia deferazyroksem [53].

\section{Wpływ na poprawę hematologiczną}

Do badania EPIC włączono pacjentów $z$ niedokrwistościami zależnymi od transfuzji (1744 chorych): talasemiami (1115), MDS (341), anemią aplastyczną (116), niedokrwistością sierpowatokrwinkową (80 chorych) [50, 51]. Wspomniani chorzy na MDS nie byli leczeni innymi metodami, przewidywane u nich OS przekraczało rok i stwierdzono u nich IO [54]. Odpowiedź czerwonokrwinkową, płytkową i neutrofilową, zgodnie $z$ oceną 
według Międzynarodowej Grupy Roboczej (IWG, International Working Group), obserwowano, odpowiednio, u 26,6\%, 14\% i 19,6\% chorych na MDS, przez rok stosowania leczenia deferazyroksem [55]. Mediana czasu do odpowiedzi hematologicznej wynosiła 169 dni (zakres 84-382 dni). U chorych, którzy zareagowali na leczenie chelatorami żelaza odpowiedzią hematologiczną, obserwowano znacznie większe obniżenie stężenia ferrytyny niż u chorych, którzy nie odpowiadali na leczenie. W badaniu Lista i wsp. [56], obejmującym pacjentów leczonych deferazyroksem, odpowiedź czerwonokrwinkową obserwowano u 15\% chorych (26/173), płytkową u $22 \%$ chorych (17/77), neutrofilową u $15 \%$ chorych (8/52), neutrofilową i czerwonokrwinkową u 4 chorych, płytkową i czerwonokrwinkową u 5 osób, neutrofilową i płytkową u 3 osób, natomiast czerwonokrwinkową, neutrofilową i płytkową łącznie u 2 osób. Mediana stężenia ferrytyny obniżyła się o 23\% u 53\% chorych, którzy zakończyli 12 miesięcy terapii, o $36,7 \%$ u pacjentów, którzy byli leczeni przez 2 lata i o 36,5\% u pacjentów, którzy odbyli 3-letnie leczenie. Obniżenie stężenia ferrytyny korelowało $z$ obniżeniem aktywności ALT. Najczęstszymi działaniami niepożądanymi były dolegliwości żołądkowo-jelitowe i podwyższone stężenie kreatyniny [56]. Jensen i wsp. [57] opisali korzystny wpływ 5-letniego leczenia chelatującego deferoksaminą na poprawę hematopoezy i odpowiedź granulocytową u 11 chorych.

Ponadto Improta i wsp. [58] przedstawil doświadczenia dotyczące terapii 55 chorych na MDS niskiego i pośredniego-1 ryzyka leczonych deferazyroksem. Pacjentów leczono zgodnie z Consensus Guidelines on Iron Chelation Therapy. Rozpoczynano od dawki $10 \mathrm{mg} / \mathrm{kg} \mathrm{mc}$./dobę, zależnej od stężenia ferrytyny, której pomiarów dokonywano co miesiąc. Po 24 miesiącach uzyskano obniżenie stężenia ferrytyny z $2362 \pm 172 \mathrm{ng} / \mathrm{ml}$ do $1679 \pm 209 \mathrm{ng} / \mathrm{ml}$. U 16 chorych obserwowano trwałą odpowiedź hematologiczną spełniającą kryteria IWG z 2006 [55]; jeden chory stał się niezależny od transfuzji kkcz.

\section{Postępowanie w okresie}

\section{okołoprzeszczepowym}

Powyżej szeroko przedstawiono niekorzystny wpływ (skrócenie OS, zwiększona śmiertelność związaną z allo-HSCT, skrócenie DFS, zwiększenie ryzyka nawrotu) podwyższonego stężenia ferrytyny w surowicy przed allo-HSCT na wyniki leczenia [14, 17]. Sugeruje się przeprowadzenie leczenia chelatującego $\mathrm{w}$ okresie przed przeszczepieniem — między innymi dlatego, że późniejsze potencjal- ne powikłania poprzeszczepowe (jelitowa postać GvHD) mogą się nałożyć na potencjalne działania niepożądane leków chelatujących [59].

\section{Monoterapia chelatorami żelaza a leczenie skojarzone}

Należy zwrócić uwagę, że wiele danych dotyczących IO pochodzi z populacji chorych na talasemie i są one ekstrapolowane na populacje innych chorych [33]. W randomizowanym badaniu, przeprowadzonym wśród dzieci z TDT, porównywano deferoksaminę $z$ placebo, uzyskując zmniejszenie wartości LIC do 25,9 mg/g suchej tkanki wątroby w porównaniu z 42,2 mg/g w grupie kontrolnej [60]. W badaniu włoskim, obejmującym 977 chorych na TDT, obserwowano mniej zgonów w grupie leczonej deferoksaminą niż w grupie otrzymującej placebo [61, 62]. Co więcej, Brittenham i wsp. [63] obserwowali grupę 59 dzieci przez 4-10 lat i stwierdzili, że wczesne rozpoczęcie leczenia chelatującego, o intensywności proporcjonalnej do stopnia IO, obniża stężenie LIC oraz ryzyko cukrzycy i chorób serca lub przedwczesnego zgonu u tych pacjentów. W kolejnych badaniach Davis i Porter [64] udowodnili, że podanie dawek do $60 \mathrm{mg} / \mathrm{kg} \mathrm{mc}$./ /dobę może zmniejszyć ilość żelaza w mięśniu sercowym i cofnąć niekorzystne zmiany.

Borgna-Pignatti i wsp. [62] zaobserwowali, że leczenie deferypronem zapewniało chorym na TDT większą kardioprotekcję niż leczenie deferoksaminą. Piga i wsp. [65] stwierdzili, że chorych leczonych deferypronem $w$ porównaniu $z$ chorymi leczonym deferoksaminą cechowało dłuższe przeżycie wolne od niekorzystnych zdarzeń. W metaanalizie 9 badań klinicznych stwierdzono, że u 75,5\% chorych z IO, leczonych deferypronem w dawce $75 \mathrm{mg} /$ /kg mc./dobę przez co najmniej 16 miesięcy, uzyskiwano obniżenie stężenia ferrytyny o 23,5\% [66]. $\mathrm{W}$ innym randomizowanym badaniu klinicznym $z$ roczną obserwacją, do którego włączono 144 chorych TDT, stwierdzono, że deferypron jest równie skuteczny jak deferoksamina w leczeniu IO u tych chorych [67]. W badaniu Andersona i wsp. [68] zaobserwowano, że zmniejszenie depozytów żelaza i poprawa frakcji wyrzutowej są większe $\mathrm{u}$ chorych leczonych deferypronem niz deferoksaminą. W 2000 roku Modell i wsp. [61] opublikowali wyniki rejestru retrospektywnego talasemii, w którym stwierdzono, że około 50\% chorych na talasemię $\beta$ umiera przed 35. rokiem życia, gdy $\dot{z}$ schemat leczenia jest zbyt uciążliwy, aby chory mógł w pełni współpracować i poddawać się leczeniu. Z kolei Kirk i wsp. [69] wykonali analizę 
funkcji serca chorych na TDT. Uwzględniono w niej dane 652 pacjentów (1442 badań MRI) z 21 centrów hematologicznych w Wielkiej Brytanii $z$ lat 1999-2006. Wykazano, że badanie MRI serca miało większą wartość w predykcji zdarzeń sercowych niż stężenie ferrytyny czy zawartość żelaza w wątrobie. Można przewidywać, że wczesne włączenie leczenia mogłoby zapobiec wystąpieniu tych powikłań. Podobne wyniki uzyskali Pennell i wsp. [70], którzy przeprowadzili analizę danych retrospektywnych $z$ rejestru UK dotyczącego TDT, stwierdzając poprawę frakcji wyrzutowej serca u chorych leczonych chelatorami żelaza. W badaniach podkreślano konieczność cotygodniowego monitorowania morfologii krwi ze względu na ryzyko agranulocytozy (ChPL Ferriprox ${ }^{\circledR}$ ) [34].

W badaniu prospektywnym ESCALATOR u chorych $z$ TDT, leczonych wcześniej deferypronem i/lub deferoksaminą, stwierdzono, $\dot{z} \mathrm{e}$ dzięki odpowiedniemu dawkowaniu deferoksaminy uzyskiwano dobre wyniki leczenia pacjentów $z$ ciężkim IO [71]. W badaniu retrospektywnym dotyczącym leczenia IO u chorych na talasemię $\mathrm{i}$ inne niedokrwistości zależne od transfuzji kkcz stwierdzono, że stosowanie deferazyroksu w dawkach ponad $30 \mathrm{mg} / \mathrm{kg} \mathrm{mc}$./dobę efektywnie obniżało stężenie ferrytyny do wartości niższych niż przed eskalacją dawki, nie wpływając na bezpieczeństwo stosowanego leczenia [71]. Deugnier i wsp. [72] zaobserwowali, że stosowanie 3-letniej terapii deferazyroksem odwracało lub zatrzymywało postęp włóknienia wątroby. W rocznym badaniu prospektywnym EPIC, do którego włączono chorych z poprzetoczeniowym IO wtórnym do niedokrwistości o różnej etiologii, stwierdzono, że ważne jest podtrzymanie wstępnie rekomendowanych dawek deferazyroksu, których zmiana może następować w zależności od stężenia ferrytyny i markerów bezpieczeństwa [51]. Rekomendowana dawka początkowa to $20 \mathrm{mg} / \mathrm{kg} \mathrm{mc}$./dobę u chorych otrzymujących 2-4 j. kkcz/miesiąc. Zależnie od częstości transfuzji kkcz można też rozważać dawkę 10 lub $30 \mathrm{mg} / \mathrm{kg} \mathrm{mc}$./dobę [51]. W subanalizach badania EPIC dowiedziono, że dawka deferazyroksu $20 \mathrm{mg} / \mathrm{kg} \mathrm{mc}$./dobę pozwalała uzyskać stężenie LIC obniżone do wartości poniżej $7 \mathrm{mg}$ żelaza/g suchej masy. Obniżenie stężenia LIC z $14 \mathrm{mg}$ żelaza/g suchej tkanki wymagało zastosowania deferazyroksu w dawce $30 \mathrm{mg} / \mathrm{kg} /$ dobę. W rozszerzeniu analizy kardiologicznej badania EPIC wykazano, że w grupie 71 chorych w ciagu 3 lat stosowania deferazyroksu zaobserwowano istotne zmniejszenie IO serca i u $68,1 \%$ chorych doszło do normalizacji T2 z wartości między $10 \mathrm{~ms}$ a $20 \mathrm{~ms}$ [73].
W badaniu CORDELIA udowodniono, że stosowanie deferazyroksu nie powoduje gorszych wyników (badanie non-inferiority) niż stosowanie deferypronu u chorych na TDT z IO serca, które nie miało jeszcze odzwierciedlenia w pogorszeniu jego funkcji [74].

\section{Skojarzenie deferoksaminy $\mathrm{z}$ deferypronem}

Skojarzenie deferoksaminy $z$ deferypronem stosowano u chorych, którzy nie uzyskali wystarczającej odpowiedzi na leczenie chelatujące deferypronem [33]. $Z$ randomizowanych badań klinicznych u pacjentów $z$ IO serca wynika, że deferypron wykazuje lepsze działanie niż deferoksamina. Deferypron podawany w skojarzeniu $z$ deferoksaminą pozwala na uzyskanie lepszych wyników niż stosowany $\mathrm{w}$ monoterapii, natomiast stosowanie deferoksaminy lub deferypronu w monoterapii jest równorzędne [75]. W badaniu El-Beshlawy i wsp. [76] stwierdzono, że skojarzone leczenie deferypronem (codziennie) $z$ deferoksaminą ( $2 \times /$ tydzień) jest dobrą alternatywą dla deferypronu w monoterapii. Zaobserwowano, że protokoły skojarzone umożliwiają uzyskanie poprawy rokowania u chorych na TDT; skojarzenia leków chelatujących mogą być szczególnie wskazane w IO serca, a w trakcie ich stosowania nie stwierdzono bardziej nasilonych powikłań niż w przypadku monoterapii wyżej wymienionymi lekami [33].

\section{Skojarzenie deferoksaminy i deferazyroksu}

W badaniu pilotażowym obejmującym 14 chorych na TDT i $z$ istotnym IO wykazano istotne obniżenie wartości LIC [77]. Grady i wsp. [78] przeprowadzili bilans żelazowy u 6 chorych leczonych deferazyroksem w monoterapii $(30 \mathrm{mg} / \mathrm{kg}$ mc./d.), deferoksaminą w monoterapii (40 mg/kg $\mathrm{mc} . / \mathrm{d}$.) oraz terapią skojarzoną deferazyroksem (30 mg/kg/dobę) i deferoksaminą (40 mg/kg mc./d.). Ustalono, że stosowanie 2-3-dniowej terapii deferoksaminą i ciągłej terapii deferazyroksem prowadzi do ujemnego bilansu żelazowego [78]. Lal i wsp. [79] raportowali zmniejszenie stężeń ferrytyny i LIC oraz IO serca w przypadku stosowania deferazyroksu (20-30 mg/kg mc./d.) i deferoksaminy (35-50 mg/kg mc. w dniach 3-5/tydzień). W badaniu klinicznym HYPERION (NCT01254227) [80] stosowano skojarzoną terapię deferoksaminą i deferazyroksem, a następnie kontynuowano leczenie deferazyroksem $\mathrm{w}$ monoterapii $\mathrm{u}$ chorych $z$ IO serca. Po 12-miesięcznej terapii uzyskano zmniejszenie IO serca $z$ profilem działań niepożądanych zbliżonym do notowanego w przypadku stosowania tych leków w monoterapii [80]. 


\section{Leczenie skojarzone deferypronem i deferazyroksem}

Skojarzone leczenie deferypronem i deferazyroksem jest przedmiotem kilku pojedynczych badań i opisów przypadków klinicznych, w których wykazano efektywność u pojedynczych chorych [81]. W celu uzyskania bardziej miarodajnych wyników konieczne jest przeprowadzenie badań randomizowanych.

\section{Postępowanie u chorych z IO utrzymującym się po allo-HSCT}

Stwierdzono zwiększone ryzyko wystąpienia zwłóknienia wątroby i kardiomiopatii u dzieci poddanych allo-HSCT $z$ powodu talasemii, które stały się niezależne od przetoczeń kkcz, a u których nadal stwierdzano IO. Mało jest danych o rozwoju uszkodzeń narządowych z utrzymującym się IO po allo-HSCT u dorosłych. U wszystkich poddanych procedurze przeszczepienia komórek krwiotwórczych zaleca się pomiar stężenia ferrytyny w surowicy rok po transplantacji i w dalszych latach.

W pierwszych tygodniach i miesiącach po allo-HSCT wzrost stężenia ferrytyny może być spowodowany zakażeniami (białko ostrej fazy), aGvHD $z$ fazą jelitową i współistniejącym zakażeniem przewodu pokarmowego. Meyer i wsp. [82] stwierdzili stężenie ferrytyny powyżej $1000 \mu \mathrm{g} / 1$ u $62 \%$ spośród 280 chorych przed transplantacją, u $64 \%$ po 6 miesiącach po allo-HSCT, u $51 \%$ po 12 miesiącach, u $38 \%$ po 24 miesiącach oraz u $12 \%$ po 60 miesiącach. Stwierdzono, że chorych z podwyższonym powyżej mediany $(1322 \mu \mathrm{g} / \mathrm{l})$ stężeniem ferrytyny w okresie przed przeszczepieniem cechowało gorsze przeżycie we wszystkich badanych punktach czasowych. Po 5 latach obserwacji u większości chorych doszło do normalizacji stężenia ferrytyny, co można tłumaczyć wykorzystaniem żelaza przez erytropoezę. Problemem są chorzy $z$ utrzymującym się IO, ponieważ nie ma ostatecznych wytycznych wskazujących, kiedy rozpoczynać u nich leczenie. U chorych w późnym ( $>1$ roku) okresie po allo-HSCT $z$ potwierdzonym IO powinno się wykonać badanie genetyczne wykluczające hemochromatozę wrodzoną (C282Y). Potwierdzenie hemochromatozy wrodzonej jest wskazaniem do flebotomii. Chorzy, u których nie stwierdzono choroby genetycznej, $z$ wysokim stężeniem ferrytyny w późnym okresie po allo-HSCT, także są kandydatami do leczenia krwioupustami lub chelatorami żelaza. Upust krwi (u chorych $z$ prawidłowym stężeniem $\mathrm{Hb}$ ) powinien wynosić $300-500 \mathrm{ml}$ (5 ml/kg mc.), co 2-4 tygodni, zależnie od tolerancji chorego, aż do normalizacji stężenia ferrytyny (lub jego obniżenia do 500-1000 ng/ml). Równolegle $z$ flebotomią lub w drugiej linii można stosować leki chelatujące żelazo [83].

Majhail i wsp. [84] zakwalifikowali do badania prospektywnego 16 pacjentów z IO (spośród 147 chorych po allo-HSCT) do leczenia obniżającego stężenia ferrytyny i LIC. U 4 stwierdzili uszkodzenia narządowe spowodowane IO (u 2 dysfunkcję wątroby i u 2 HF). U chorych, którym wykonywano krwioupusty (8 osób) oraz leczono deferazyroksem (4 osoby), uzyskano obniżenie stężeń ferrytyny i LIC. W badaniu IV fazy Vallejo i wsp. [85] wykazano, że deferazyroks w dawce $10 \mathrm{mg} / \mathrm{kg} \mathrm{mc}$., podawany przez 52 tygodnie w okresie potransplantacyjnym, spowodował istotne obniżenie wartości ferrytyny i LIC.

\section{Podsumowanie}

Przeładowanie żelazem przyczynia się do uszkodzenia tkanek i narządów. Ważna jest kontrola gospodarki żelazem (stężenie ferrytyny w surowicy) u chorych uzależnionych od przetoczeń kkcz, która pozwoli na podjęcie decyzji o rozpoczęciu leczenia chelatorami żelaza w odpowiednim czasie. Przedstawione wyniki badań leczenia chelatującego są obiecujące. Ograniczeniami tych badań, w których analizowano przeżycie, funkcję uszkodzonych narządów oraz ryzyko transformacji do ostrej białaczki, są: nierandomizowany i obserwacyjny charakter badań, zróżnicowany czas od rozpoznania do rozpoczęcia leczenia, różny czas trwania leczenia chelatującego, fakt kierowania się stanem klinicznym chorego przy kwalifikacji do leczenia chelatującego i możliwym włączaniem chorych „lepiej rokujących”. W przypadku leczenia chelatującego istotna jest ocena tolerancji leczenia oraz jego kosztów.

\section{Piśmiennictwo}

1. Porter J.B. Practical management of iron overload. Br. J. Haematol. 2001; 115: 239-225.

2. Porter J.B. Pathophysiology of iron overload. Hematol./Oncol. Clin. 2005; 19: 7-12.

3. Gattermann N., Rachmilewitz E.A. Iron overload in MDS-pathophysiology, diagnosis, and complications. Ann. Hematol. 2011; 90: 1-10.

4. Jaeger M., Aul C., Sohngen D. i wsp. Secondary hemochromatosis in polytransfused patients with myelodysplastic syndromes. Beitr. Infusionsther. 1992; 30: 464-468.

5. Wood J.C., Enriquez C., Ghugre N. i wsp. Physiology and pathophysiology of iron cardiomyopathy in talassemia. Ann. NY Acad. Sci. 2005; 1054: 386-395. 
6. Kirk P., Roughton M., Porter J.B. i wsp. Cardiac T2* magnetic reasonance for prediction of cardiac complication in talassemia major. Circulation 2009; 120: 1961-1968.

7. Takatoku M., Uchiyama T., Okamoto S. i wsp. Retrospective rationale survey of Japanese patients with transfusion-dependent MDS and aplastic anemia highlights the negative impact of iron overload on morbiditity/mortality. Eur. J. Haematol. 2007; 78: 487-494.

8. Malcovati L., Porta M.G., Pascutto C. i wsp. Prognostic factors and life expectancy in myelodysplastic syndromes classified according to WHO criteria: a basis for clinical decision making. J. Clin. Oncol. 2005; 23: 7594-7603.

9. Malcovati L. Impact of transfusion dependency and secondary iron overload on the survival of patients with myelodysplastic syndromes. Leuk. Res. 2007; 31: S2-S6.

10. Cazzola M., Della Porta M.G., Malcovati L. Clinical relevance of anemia and transfusion iron overload in myelodysplastic syndromes. Hematology Am. Soc. Hematol. Educ. Program 2008: 166-175.

11. Hartmann J., Braulke F., Sinzig U. i wsp. Iron overload impairs proliferation of erythroid progenitors cells (BFU-E) from patients with myelodysplastic syndromes. Leuk. Res. 2013; 37: 327-332.

12. Gale E., Torrance J., Bothwell T. The quantitative estimation of total iron stores in human bone marrow. J. Clin. Invest. 1963; 42: 1076-1082.

13. Storey J.A., Connor R.F., Lewis Z.T. i wsp. The transplant iron score as a predictor of stem cell transplant survival. J. Hematol. Oncol. 2009; 24: 44.

14. Lim Z.Y., Fiaccadori Z.F., Gandhi S.G. i wsp. Pre-transplant serum ferritin as an independent prognostic factor in MDS patients undergoing reduced intensity conditioning HSCT. Haematologica 2008; 93: abstrakt 0235.

15. Pullarkat V., Blanchard S., Tegtmeier B. i wsp. Iron overload adversely affects outcome of allogeneic hematopoietic cell transplantation. Bone Marrow Transplant. 2008; 42: 799-805.

16. Kataoka K., Nannya Y., Hangaishi A. i wsp. Influence of pretransplantation serum ferritin on nonrelapse mortality after myeloablative and nonmyeloablative allogeneic hematopoietic stem cell transplantation. Biol. Blood Marrow Transplant. 2009; 15: 195-204.

17. Armand P., Kim H.T., Cutler C.S. i wsp. Prognostic impact of elevated pretransplantation serum ferritin in patients undergoing myeloablative stem cell transplantation. Blood 2007; 109: 4586-4588.

18. Garcia Delgado R., de Miguel D., Bailen A. i wsp. Multivariate analysis of the impact of pre-treatment serum ferritin level on response and overall survival in patients with myelodysplastic syndromes treated with azacitidine. ASH 2012; plakat 1710.

19. Bullen J.J., Rogers H.J., Spalding P.B., Ward C.G. Natural resistance, iron and infection: a challenge for clinical medicine. J. Med. Microbiol. 2006; 55: 251-258.

20. Kontoghiorghes G.J., Spyrou A., Kolnagou A. Iron chelation therapy in hereditary hemochromatosis and thalassemia intermedia: regulatory and non-regulatory mechanisms of increased iron absorption. Hemoglobin 2010; 34: 251-264.

21. Gattermann N. Guidelines on iron chelation therapy in patients with myelodysplastic syndromes and transfusional iron overload. Leuk. Res. 2007; 31: 10-15.

22. Alessandrino E.P., Amadori S., Barosi G. i wsp. Evidence- and consensus-based practice guidelines for the therapy of primary myelodysplastic syndromes: a statement from the Italian Society of Hematology. Haematologica 2002; 87: 1286-1306.
23. Bowen D., Culligan D., Jowitt S. i wsp. Guidelines for the diagnosis and therapy of adult myelodysplastic syndromes. Br. J. Haematol. 2003; 120: 187-200.

24. Suzuki T., Tomonaga M., Miyazaki Y. i wsp. Japanese epidemiological survey with consensus statement on Japanese guidelines for treatment of iron overload in bone marrow failure syndromes. Int. J. Hematol. 2008; 88: 30-35.

25. National Comprehensive Cancer Network, NCCN Clinical Practice Guidelines in Oncology, Myelodysplastic Syndromes, Version 1.2016. Dostępne na: http://www.nccn.org/professionals/physician_gls/pdf/mds.pdf. Dostęp: 31.03.2016.

26. Woodcock B. Guideline for iron chelation therapy in myelodysplasia (MDS). Merseyside and Cheshire Cancer Network. National Health Service 2010. Dostępne na: http://www.mccn.nhs. uk/userfiles/documents/Guidelines\%20for\%20Iron\%20Chelation\%20Therapy\%20in\%20Myelodysplasia\%20_MDS_\%20February\%202010.pdf. Dostęp: 31.03.2016.

27. Bennett M. MDS Foundation Working Group on Transfusional Iron Overload. Consensus statement on iron overload in MDS. Am. J. Hematol. 2008; 83: 858-861.

28. Ko B.S., Chang C.S., Chang M.C. i wsp. Guidelines for treating iron overload in myelodysplastic syndromes: a Taiwan consensus statement. Int. J. Hematol. 2014; 100: 7-15.

29. Dwilewicz-Trojaczek J. Przeładowanie żelazem u chorych na zespoły mielodysplastyczne. Acta Haematol. Pol. 2009; 40: 475-479.

30. Dwilewicz-Trojaczek J., Deptała A., Hellmann A. i wsp. Diagnostyka, klasyfikacja i leczenie zespołów mielodysplastycznych — zalecenia ekspertów polskich. Acta Haematol. Pol. 2010; 41: 101-114.

31. Steensma D.P., Gattermann N. When is iron overload deleterious, and when and how should iron chelation therapy be administered in myelodysplastic syndromes? Best Pract. Res. Clin. Haematol. 2013; 26: 431-444.

32. Charakterystyka Produktu Leczniczego Desferal.

33. Lee J.W., Kang H.J., Kim E.K. i wsp. Effect of iron overload and iron-chelating therapy on allogeneic hematopoietic SCT in children. Bone Marrow Transplant. 2009; 44: 793-797.

34. Charakterystyka Produktu Leczniczego Ferriprox.

35. Charakterystyka Produktu Leczniczego Exjade.

36. Lee J.W., Yoon S.S., Shen Z.X. i wsp.; EPIC Study Investigators. Iron chelation therapy with deferasirox in patients with aplastic anemia: a subgroup analysis of 116 patients from the EPIC trial. Blood 2010; 116: 2448-2454.

37. Santini V., Alessandrino P.E., Angelucci E. i wsp. Italian Society of Hematology. Clinical management of myelodysplastic syndromes: update of SIE, SIES, GITMO practice guidelines. Leuk. Res. 2010; 34: 1576-1588.

38. Messa E., Carturan S., Maffè C. i wsp. Deferasirox is a powerful NF-kappaB inhibitor in myelodysplastic cells and in leukemia cell lines acting independently from cell iron deprivation by chelation and reactive oxygen species scavenging. Haematologica 2010; 95: 1308-1316.

39. Kwiatkowski J.L. Oral iron chelators. Pediatr. Clin. North Am. 2008; 55: 461-482.

40. Mainous A.G. 3rd, Tanner R.J., Hulihan M.M. i wsp. The impact of chelation therapy on survival in transfusional iron overload: a meta-analysis of myelodysplastic syndrome. Br. J. Haematol. 2014; 167: 720-723.

41. Rose C., Brechignac S., Vassilief D. i wsp. Does iron chelation therapy improve survival in regularly transfused lower risk MDS patients? A multicenter study by the GFM. Leuk. Res. 2010; 34: 864-870. 
42. Leitch H.A., Leger C.S., Goodman T.A. i wsp. Improved survival in patients with myelodysplastic syndrome receiving iron chelation therapy. Clin. Leuk. 2008; 2: 205-211.

43. Leitch H.A., Chan C., Leger C.S. i wsp. Improved survival with iron chelation therapy for red blood cell transfusion dependent lower IPSS risk MDS may be more significant in patients with a non-RARS diagnosis. Leuk. Res. 2012; 36: 1380-1386.

44. Neukirchen J., Fox F., Kündgen A. i wsp. Improved survival in MDS patients receiving iron chelation therapy — a matched pair analysis of 188 patients from the Düsseldorf MDS registry. Leuk. Res. 2012; 36: 1067-1070.

45. Lyons R.M., Marek B.J., Paley C. i wsp. Comparison of 24-month outcomes in chelated and non-chelated lower-risk patients with myelodysplastic syndromes in a prospective registry. Leuk. Res. 2014; 38: 149-154.

46. Delforge M., Selleslag D., Beguin Y. i wsp. Adequate iron chelation therapy for at least six months improves survival in transfusion-dependent patients with lower risk myelodysplastic syndromes. Leuk. Res. 2014; 38: 557-563.

47. Remacha Á.F., Arrizabalaga B., Villegas A. i wsp. IRON-2 Study Group. Evolution of iron overload in patients with low-risk myelodysplastic syndrome: iron chelation therapy and organ complications. Ann. Hematol. 2015; 94: 779-787.

48. Komrokji R.S., Al Ali N.H., Padron E. i wsp. Impact of iron chelation therapy on overall survival and AML transformation in lower risk MDS patients treated at the Moffitt Cancer Center. Blood 2011; 118: abstrakt 2776.

49. Kersten M.J., Lange R., Smeets M.E. i wsp. Long-term treatment of transfusional iron overload with the oral iron chelator deferiprone (L1): a Dutch multicenter trial. Ann. Hematol. 1996; 73: 247-252.

50. Gattermann N., Finelli C., Porta M.D. i wsp.; EPIC Study Investigators. Deferasirox in iron-overloaded patients with transfusiondependent myelodysplastic syndromes: Results from the large 1-year EPIC study. Leuk. Res. 2010; 34: 1143-1150.

51. Cappellini M.D., Porter J., El-Beshlawy A. i wsp.; EPIC Study Investigators. Tailoring iron chelation by iron intake and serum ferritin: the prospective EPIC study of deferasirox in 1744 patients with transfusion-dependent anemias. Haematologica 2010; 95: 557-566.

52. Cheong J.W., Kim H.J., Lee K.H. i wsp.; Korean Society of Hematology Acute Myeloid Leukemia/Myelodysplastic Syndrome Working Party. Deferasirox improves hematologic and hepatic function with effective reduction of serum ferritin and liver iron concentration in transfusional iron overload patients with myelodysplastic syndrome or aplastic anemia. Transfusion 2014; 54: 1542-1551.

53. Greenberg P.L., Koller C.A., Cabantchik Z.I. i wsp. Prospective assessment of effects on iron-overload parameters of deferasirox therapy in patients with myelodysplastic syndromes. Leuk. Res. 2010; 34: 1560-1565.

54. Gattermann N., Finelli C., Della Porta M. i wsp. Hematologic responses to deferasirox therapy in transfusion-dependent patients with myelodysplastic syndromes. Haematologica 2012; 97: 1364-1371.

55. Cheson B.D., Greenberg P.L., Bennett J.M. i wsp. Clinical application and proposal for modification of the International Working Group (IWG) response criteria in myelodysplasia. Blood 2006; 108: 419-425.

56. List A.F., Baer M.R., Steensma D.P. i wsp. Deferasirox reduces serum ferritin and labile plasma iron in RBC transfusion-depend- ent patients with myelodysplastic syndrome. J. Clin. Oncol. 2012; 30: 2134-2139.

57. Jensen P.D., Heickendorff L., Pedersen B. i wsp. The effect of iron chelation on haemopoiesis in MDS patients with transfusional iron overload. Br. J. Haematol. 1996; 94: 288-299.

58. Improta S., Villa M.R., Volpe A. i wsp. Transfusion-dependent low-risk myelodysplastic patients receiving deferasirox: long-term follow-up. Oncol. Lett. 2013; 6: 1774-1778.

59. Saliba A.N., Harb A.R., Taher A.T. Iron chelation therapy in transfusion-dependent thalassemia patients: current strategies and future directions. J. Blood Med. 2015; 6: 197-209.

60. Barry M., Flynn D.M., Letsky E.A., Risdon R.A. Long-term chelation therapy in thalassaemia major: effect on liver iron concentration, liver histology, and clinical progress. Br. Med. J. 1974; 2: 16-20.

61. Modell B., Letsky E.A., Flynn D.M. i wsp. Survival and desferrioxamine in thalassaemia major. Br. Med. J. 1982; 284: 1081-1084.

62. Borgna-Pignatti C., Rugolotto S., De Stefano P. i wsp. Survival and complications in patients with thalassemia major treated with transfusion and deferoxamine. Haematologica 2004; 89: 1187-1193.

63. Brittenham G.M., Griffith P.M., Nienhuis A.W. i wsp. Efficacy of deferoxamine in preventing complications of iron overload in patients with thalassemia major. N. Engl. J. Med. 1994; 331: 567-573.

64. Davis B.A., Porter J.B. Long-term outcome of continuous 24-hour deferoxamine infusion via indwelling intravenous catheters in high-risk beta-thalassemia. Blood 2000; 95: 1229-1236.

65. Piga A., Gaglioti C., Fogliacco E., Tricta F. Comparative effects of deferiprone and deferoxamine on survival and cardiac disease in patients with thalassemia major: a retrospective analysis. Haematologica 2003; 88: 489-496.

66. Addis A., Loebstein R., Koren G., Einarson T.R. Meta-analytic review of the clinical effectiveness of oral deferiprone (L1). Eur. J. Clin. Pharmacol. 1999; 55: 1-6.

67. Maggio A., D’Amico G., Morabito A. i wsp. Deferiprone versus deferoxamine in patients with thalassemia major: a randomized clinical trial. Blood Cells Mol. Dis. 2002; 28: 196-208.

68. Anderson L.J., Wonke B., Prescott E. i wsp. Comparison of effects of oral deferiprone and subcutaneous desferrioxamine on myocardial iron concentrations and ventricular function in betathalassaemia. Lancet 2002; 360: 516-520.

69. Kirk P., Roughton M., Porter J.B. i wsp. Cardiac T2* magnetic resonance for prediction of cardiac complications in thalassemia major. Circulation 2009; 120: 1961-1968.

70. Pennell D.J., Carpenter J.P., Roughton M. i wsp. On improvement in ejection fraction with iron chelation in thalassemia major and the risk of future heart failure. J. Cardiovasc. Magn. Reson. 2011; 13: 45.

71. Taher A., Aoun E., Sharara A.I. i wsp. Five-year trial of deferiprone chelation therapy in thalassaemia major patients. Acta Haematol. 2004; 112: 179-183.

72. Deugnier Y., Turlin B., Ropert M. i wsp. Improvement in liver pathology of patients with beta-thalassemia treated with deferasirox for at least 3 years. Gastroenterology 2011; 141: 1202-1211.

73. Pennell D.J., Porter J.B., Cappellini M.D. i wsp. Deferasirox for up to 3 years leads to continued improvement of myocardial $\mathrm{T} 2 *$ in patients with beta-thalassemia major. Haematologica 2012; 97: 842-848.

74. Pennell D.J., Porter J.B., Piga A.; CORDELIA Study Investigators i wsp. A 1-year randomized controlled trial of deferasirox vs deferoxamine for myocardial iron removal in beta-thalassemia major (CORDELIA). Blood 2014; 123: 1447-1454.

75. Pennell D.J., Udelson J.E., Arai A.E.; American Heart Association Committee on Heart Failure and Transplantation of the Council 
on Clinical Cardiology and Council on Cardiovascular Radiology and Imaging i wsp. Cardiovascular function and treatment in betathalassemia major: a consensus statement from the American Heart Association. Circulation 2013; 128: 281-308.

76. El-Beshlawy A., Manz C., Naja M. i wsp. Iron chelation in thalassemia: combined or monotherapy? The Egyptian experience. Ann. Hematol. 2008; 87: 545-550.

77. Maggio A., Filosa A., Vitrano A. i wsp. Iron chelation therapy in thalassemia major: a systematic review with meta-analyses of 1520 patients included on randomized clinical trials. Blood Cells Mol. Dis. 2011; 47: 166-175.

78. Grady R.W., Galanello R., Randolph R.E. i wsp. Toward optimizing the use of deferasirox: potential benefits of combined use with deferoxamine. Haematologica 2013; 98: 129-135.

79. Lal A., Porter J., Sweeters N. i wsp. Combined chelation therapy with deferasirox and deferoxamine in thalassemia. Blood Cells Mol. Dis. 2013; 50: 99-104.

80. Aydinok Y., Kattamis A., Cappellini M.D. i wsp. Deferasirox-deferoxamine combination therapy reduces cardiac iron with rapid liver iron Removal in patients with severe transfusional iron overload (HYPERION). W: 55 ${ }^{\text {th }}$ ASH Annual Meeting; 8 grudnia 2013, Nowy Orlean.
81. Voskaridou E., Christoulas D., Terpos E. i wsp. Successful chelation therapy with the combination of deferasirox and deferiprone in a patient with thalassaemia major and persisting severe iron overload after single-agent chelation therapies. Br. J. Haematol. 2011; 154: 654-656.

82. Meyer S.C., O’Meara A., Buser A.S. i wsp. Prognostic impact of posttransplantation iron overload after allogeneic stem cell transplantation. Biol. Blood Marrow Transplant. 2013; 19: 440-444.

83. Fred Hutchinson Cancer Research Center and Seattle Cancer Care Alliance, 2014. Long-term follow-up after hematopoietic stem cell transplant: general guidelines for referring physicians. Dostępne na: https://www.fredhutch.org/content/dam/public/Treatment-Suport/Long-Term-Follow-Up/physician.pdf. Dostęp: 17.07.2014.

84. Majhail N.S., Lazarus H.M., Burns L.J. Iron overload in hematopoietic cell transplantation. Bone Marrow Transplant. 2008; 41: 997-1003.

85. Vallejo C., Batlle M., Vázquez L. i wsp. Subcommittee of Non-Infectious Complications of the Grupo Español de Trasplante Hematopoyético (GETH). Phase IV open-label study of the efficacy and safety of deferasirox after allogeneic stem cell transplantation. Haematologica 2014; 99: 1632-1637. 